\title{
Meet Your New Marketing Team: the Regulators
}

\author{
Yasuhiro (Yasu) Yamakawa (Babson College) \\ Reiko Kishida \\ David Deeds (University of St. Thomas) \\ Bill Schulze (University of Utah)
}

KEYWORDS: Innovation.

\section{Abstract}

This exploratory study investigates how competitive and institutional factors jointly affect new venture performance. Specifically, we examine the relationship among new ventures' product innovation capabilities (i.e., ability to introduce new products), legitimation capabilities (i.e., ability to manage internal and external contexts), the level of regulatory pressure in the environment, and how it affects new venture performance. A theoretical model is developed by synthesizing the strategic and institutional perspectives, and hypotheses are tested with a sample of venture firms in various manufacturing industries across the United States. Results indicate that the capabilityperformance relationships differ across various institutional (regulatory) contexts.

\section{Introduction}

Under what condition does regulatory pressure stimulate or constrain the relationship between new ventures' innovation/legitimation capabilities and performance? While new ventures' abilities to carry out product innovation and to secure organizational legitimacy have been recognized as important variables to explain entrepreneurial outcomes (Aldrich, 1999; Deeds, Mang, \& Frandsen, 2004; Hargadon \& Douglas, 2001; Schumpeter, 1934) the impact of the regulatory pressure ventures face in the environment in which they operate, on the relationship between these capabilities and performance has not been systematically considered. A substantial proportion of research on new ventures and legitimacy has studied the highly regulated environment of the Biopharmaceutical industry (e.g., Deeds et al., 2004; Higgins \& Gulati, 2003, 2006; Kuratko \& Brown, 2010; Powell, Koput, \& Smith-Doerr, 1996; Rao, Chandy, \& Prabhu, 2008; Stuart, Hoang, \&
Hybels, 1999); however, there is clearly a gap in the literature, which we attempt to fill with this study. Using survey data of new ventures from nine industries, which face distinctly different levels of regulatory pressure, we empirically examine the relationship among firms' innovative and legitimating capabilities, and new venture performance, paying particular attention to the moderating impact of industry regulatory pressure on the relationship among these variables.

In this study we define legitimacy as "a generalized perception or assumption that the actions of an entity are desirable" (Suchman, 1995). New ventures frequently suffer from a lack of legitimacy in the eyes of important stakeholders, such as venture capitalists, stock market analysts, employees and consumers (DiMaggio, 1988). This lack of legitimacy is partly what creates a liability of newness for such firms (Stuart et al., 1999), and the abilities of ventures to legitimate their actions are what help to overcome it. Building on prior work (Deephouse, 1999; Meyer \& Rowan, 1977; Scott, 1987; Zucker, 1987) we begin with the idea that institutional environment generates various pressures to conform to social norms, values and taken-for-grated rules by prescribing not only what organizations should do but what they should not, and also what is seen as valuable and appropriate (Scott, 1987). Building on Scott (1987) and Oliver (1991) we define institutions as regulatory structures, governmental agencies, laws, courts, and professions that pressure organizations to act within certain constraints or norms. While the broad institutional environment and the pressure it creates is likely to be critical to new ventures, this article will focus specifically on a subset of the institutional environment that is the regulatory environment and the perceived pressure it exerts on the operations of ventures in various industries. The perceived pressure on a venture to conform its activities, practices and offerings to those specified by regulations is likely to vary across 
industries. This variation is what we define as regulatory pressure. Specifically, we define regulatory pressure as the perception of the participants in an industry regarding the strength of these forces to constrain their actions and enforce conformance in their activities, practices, and offerings.

The strategic and institutional perspectives have yielded conflicting arguments on the success factors of new ventures (Lounsbury \& Glynn, 2001). On the one hand, the strategic perspective highlights the competitive mechanism that drives young firms to build and exploit their distinctive capabilities in order to develop their competitive advantage. From this logic, the more innovative products new ventures offer, the more they can fill the need for strategic distinctiveness. On the other hand, the institutional perspective emphasizes the mechanism that compels organizations to align with regulative, normative, and cognitive systems, suggesting that the more new ventures conform to existing regulations, social norms, values and taken-forgranted rules, the more they can obtain the legitimacy that enables them to gain access to resources and achieve economic success.

The resolution of this conflict between the need to innovate to be distinctive and the need to conform is critical to furthering our understanding of new venture performance. By jointly examining innovative capabilities, internal and external legitimating capabilities, and industry regulatory pressure, we hope to provide some resolution to this conflict. In sum, this study will attempt to fill in the gap in the literature by expanding our understanding of new venture performance through examining the effect of innovation and legitimation capabilities, and the moderating influence of regulatory pressure in the environment in which the venture operates.

\section{Theory and Hypotheses Theoretical Framework}

Overcoming the liability of newness (Stinchcombe, 1965) has long been identified as the key challenge to the growth and success of new ventures. As noted by Deephouse (1999) new ventures face pressures to be both different and the same. Challenging incumbents on their terms, being the same, is a recipe for a competitive disaster, but diverging from the expectations of resource providers, being different, increases risk and the difficulty of acquiring resources. To resolve this conflict, new ventures must have both the ability to innovate and to legitimate the new things that they create through their innovation. Both the ability to innovate and the ability to legitimate are critical capabilities for exploiting entrepreneurial opportunities and achieving superior performance, but beyond that, we believe that the two capabilities are synergistic, and ventures that possess strengths in both areas will outperform those with strengths in only one. Applying Oliver's (1997) resource and institutional capital framework to our entrepreneurial product innovation context, we argue that product innovation capabilities and legitimation capabilities must not only co-exist for successful innovation, but that these two capabilities are complementary. Specifically, a firm's ability to attract resources and profit from product innovation depends on the firm's effectiveness in managing its internal and external social contexts, which we aim to capture as legitimation capabilities. We further argue that the relationship between these capabilities and new venture performance will be moderated by the degree of regulatory pressure the ventures face within their industry environment. A schematic model of our study is depicted in Figure 1.

Figure 1. Model of Product Innovation and Legitimation

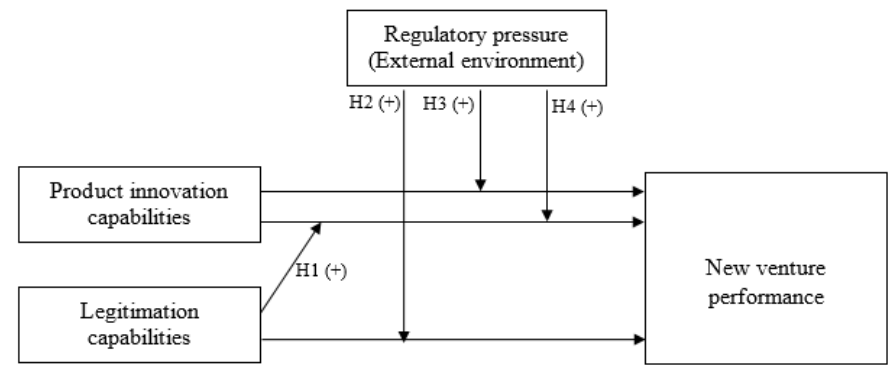

\section{Product Innovation Capabilities}

Product innovation capabilities ${ }^{1}$ (\#footnote1) are a bundle of firms' abilities to carry out innovation $^{2}$ (\#footnote2) . Researchers as well as practitioners agree that innovation is a key in pursuit of a firm's success. Particularly, new ventures have been tied with innovation that significantly raises the performance and changes competitive landscape of an economic system (Henderson \& Clark, 1990; Schumpeter, 1934; Tushman \& Anderson, 1986). History provides numerous examples of new ventures which, unconstrained with tradition, have created new products, new markets, and new wealth, while 
disrupting old industry structures and shaping new competitive environments (Timmons, 1999). Scholars argue that by introducing innovative products, new ventures can differentiate themselves from others, obtain competitive advantage, and hence superior performance (Alvarez \& Barney, 2000; Henderson \& Clark, 1990). Moreover, by bringing an innovative product into a market ahead of competitors, new ventures can gain monopoly profits as well as many other first-mover advantages such as lock-in effects of customers and suppliers (Alpert, Kamis, \& Graham, 1992; Schumpeter, 1934). Product innovation also enables new ventures to generate a superior product that satisfies market needs more adequately than existing products and win customers. Hence, as Schumpeter (1934) argued, innovation is a source of entrepreneurial profit. Innovation diffusion and marketing literatures support this line of argument, identifying product advantage as a critical factor that has systematic effects on innovation adoption and new product success. New products possessing favorable characteristics diffuse more easily and rapidly than those with less favorable characteristics, and hence, contribute to firm success (Gatignon \& Xuereb, 1997; Rogers, 1962). Particularly for new ventures that lack established relationships with customers, the ability to generate a new product with significant advantages to customers can be a fundamental source of competitive advantage to win customers and to succeed.

Although introducing a superior product is a key element of product innovation that is likely to affect new venture performance, profiting from innovation often involves introducing a stream of new products that include revisions and expansions of existing products (Brown \& Eisenhardt, 1995; Zahra \& Bogner, 2000). Success of innovative firms depends on yielding a series of innovations, updates, and expansions that translate temporary monopoly positions at product level into persistent profitability at firm level (Roberts, 1999). It has also been discussed that the success of pioneers depends on whether they can utilize an advantageous position by introducing numerous products for the largest and best market segments before followers enter the market (Kalyanaram, Robinson, \& Urban, 1995). Product innovation with broad product lines requires many firm abilities including the ability to obtain broad knowledge and expertise, the ability to generate many unique combinations of such knowledge, and the ability to leverage the opportunity of innovation (Brown \& Eisenhardt, 1995; Schoonhoven, Eisenhardt, \& Lyman,
1990). With these abilities, a new venture can increase the potential to profit from product innovation. Summarizing the arguments from the prior literature, the greater the new venture's product innovation capabilities, the greater its performance.

\section{Legitimation Capabilities}

The success of innovative organizations depends on the amount of support received from their internal and external environments (Van de Ven, 1986). In this sense, as institutional theorists (e.g., Meyer \& Rowan, 1977) and Schumpeter (1934) also suggest, achieving entrepreneurial success not only requires new ventures' abilities to introduce new products that enable them to obtain competitive advantage but also the abilities to manage internal and external contextual factors surrounding product innovation. The concept of legitimation capabilities aims to capture these abilities - the ability to manage the cultural component of the organization (i.e., internal legitimation capabilities) and the ability to gain acceptance and support from the external environment (i.e., external legitimation capabilities). These capabilities are critical to a new venture attempting to introduce novel, innovative products, which are outside the regulatory norms of the industry.

Ventures, which challenge the regulatory norms do so at their own peril. The introduction of innovative and novel new products or processes becomes the subject of legitimacy challenges. Incumbents seek to raise questions about the legitimacy, reliability, and rationality of both the product and the venture itself (Ashforth \& Gibbs, 1990; Deephouse, 1999; DiMaggio \& Powell, 1983; Hambrick \& D’Aveni, 1992; Suchman, 1995). In these situations it becomes critical for a new venture to be able to actively work to gain acceptance and support from both internal and external constituencies, particularly in light of the challenges that are likely to be introduced by the incumbents. In these conditions the capability to manage both internal and external legitimacy becomes critically important to the venture's performance. A number of studies have provided empirical support for the positive effects of organizational legitimacy on survival (Baum \& Oliver, 1991; Rao, 1994; Shane \& Delmar, 2004; Singh, Tucker, \& House, 1986), resource acquisition (Deeds et al., 2004; Zott \& Huy, 2007), and new venture performance (Khaire, 2010). Summarizing the 
arguments from prior findings, the greater the new venture's legitimation capabilities, the greater its performance and its chances of survival.

\section{The Moderating Impact of Legitimation Capabilities}

Innovation has been described as the search for novelty requiring firms to introduce something 'new' and formerly unknown to the market. This requires innovative new ventures to depart substantially from existing practice in their chosen market place, which immediately creates a potential regulatory challenge. Novelty by its nature challenges the existing order, the accepted way of doing things, and what has been takenfor-granted by the participants in the industry, which include those regulating the industry. Under these circumstances more innovative new ventures pursuing more novel products are likely to face greater problems due to their lack of regulatory legitimacy than imitators or reproducers (Aldrich \& Martinez, 2001; Low \& Abrahamson, 1997; Rao et al., 2008). Moreover, commercialization of novel technologies and market introduction of radically new products is often much more resource intensive and requires accessing a greater variety of complementary assets from beyond the boundaries of the venture in order to realize the potential value of innovation (Chandy \& Tellis, 2000; Mitchell, 1989; Teece, 1986). The literature also suggests that the more innovative the product the more resources are required to deal with uncertainties and sustain its market presence during the unprofitable period of introduction (Lynn, Morone, \& Paulson, 1996). In spite of these challenges, some novel innovators succeed in overcoming these hurdles, accessing the required resources and realize entrepreneurial profits, while many others fail. This suggests that firms' differential abilities to build their organizational legitimacy explain some of the variation in innovative new venture performance. In other words, whether new ventures can realize the potential gain from their product innovation capabilities depends on their ability to build and enhance their organizational legitimacy. In sum,

Hypothesis 1:A new venture's legitimation capabilities positively moderate the relationship between its product innovation capabilities and performance.

\section{Moderating Influence of Regulatory Pressure}

Though researchers have conceptualized the external environment in various ways, they agree that the environment affects organizations (e.g., Aldrich, 1999; Bain, 1959; Dess \& Beard, 1984; Hannan \& Freeman, 1989; Lawrence \& Lorsch, 1967; Pfeffer \& Salancik, 1978). Particularly, with few slack resources, single niche focus, and little power to control their environment, new ventures are more likely to be strongly affected by environmental factors than large established firms that have ample resources and span many niches (Aldrich \& Martinez, 2001; Astley \& Van de Ven, 1983).

The innovation literature provides rich insights indicating that a new venture's competitiveness is interdependent on a larger system that includes social and political processes of accepting and supporting (or rejecting and opposing) new ventures' innovation activities. These implications are seen in the studies of diffusion of innovation (Rogers, 1962), dominant design (Anderson \& Tushman, 1990), appropriability of regime (Teece, 1986), technology community (Van de Ven \& Garud, 1994), innovation community (Lynn et al., 1996), and national innovation systems (Nelson \& Rosenberg, 1993).

While the most commonly held conception of the organizational environment is associated with the task or competitive elements of external business environment (Covin \& Slevin, 1989; Dess \& Beard, 1984; Zahra \& Bogner, 2000) institutional theorists highlight institutional elements that encompass the regulatory, the cognitive and socio-political environment (Meyer \& Rowan, 1977; Scott, 1987; Zucker, 1987). Institutional environment generates various pressures to conform to social norms, values, and taken-for-grated rules by prescribing not only what organizations should do but what they should not and also what is seen as valuable and appropriate (Scott, 1987). These institutional elements serve to assure that the participants in the environment act appropriately, meet the expectations of the constituents of the industry, and create desirable social outcomes. Industry constituents working to achieve these goals through regulatory and normative pressures moves the industry towards isomorphic outcomes, such as dominant product designs, organizational structures and operating processes. Over time industries tend to converge on a set of structures, processes, designs and strategies that conform to the regulations and industry and professional 
norms.

For new ventures that are attempting to challenge the status quo and introduce novel new products with little power or status within the context, the pressure the institutional environment brings to bear in enforcing isomorphism and rejecting change and novelty will have a strong impact on determining their fate. The greater the regulatory and normative pressures in an industry the more resistance there is likely to be to the introduction of novel products. In particular, new ventures introducing challenging, innovative new products are likely to face substantial regulatory pressure. Under these circumstances innovative new ventures' performance is likely to be influenced by the regulatory pressure in the environment in which they operate as much as by competitive elements of the environment.

High levels of regulatory pressure will increase the importance of a venture's legitimation capabilities. The ability of the new venture to navigate in a high regulatory pressure environment and to generate legitimacy via endorsements and media coverage will become critical to establishing that the venture's products are desirable and beneficial to society. Therefore,

Hypothesis 2: Regulatory pressure will positively moderate the relationship between a new venture's legitimation capabilities and its performance.

As noted earlier, new products possessing favorable characteristics diffuse more easily and rapidly than those with less favorable characteristics, and hence, contribute to firm success (Gatignon \& Xuereb, 1997; Rogers, 1962). Particularly for new ventures that lack established relationships with customers, the ability to generate a new product with significant advantages to customers can be a fundamental source of competitive advantage to win customers and to succeed. Regulatory pressure functions as an institutional isolating mechanism which serves to keep firms from acquiring or adopting new capabilities and ways of doing business (Oliver, 1997) reinforcing the status quo and placing hurdles to the introduction of new products, processes or services. Environments with high regulatory pressure will more strongly resist change and place greater constraints on firms' actions and raise the costs of introducing new products, processes, or services. The increased costs of novelty and innovation due to the regulatory pressure will effectively screen out novel products of only modest benefit, since the returns are unlikely to be large enough to sustain the required investment. Industries with high regulatory pressure environment will therefore require new ventures to introduce more innovative products with more favorable characteristics and substantially better performance to overcome the barriers to change created by the high levels of regulatory pressure. In a high-pressure regulatory environment, given the importance of new products to a venture's success, ventures with greater innovation capabilities are likely to outperform those with weaker innovation capabilities. Therefore,

Hypothesis 3:Regulatory pressure will positively moderate the relationship between a new venture's product innovation capabilities and its performance.

Finally, as noted in the preceding arguments both innovation and legitimation capabilities are independently of greater value in environments with high regulatory pressure. They are also of greater value in combination in a high regulatory pressure environment. The more product innovations and the more novel the product innovations being introduced by a venture in a high regulatory pressure environment the greater the need for the venture to be able to create legitimacy via endorsements and media coverage in order to overcome the resistance to change created by the pressures to conform. Therefore, innovative ventures in a high regulatory pressure environment will see greater benefit from strong legitimation capabilities than innovative ventures in a low regulatory pressure environment. Thus we posit a three-way moderated interaction among regulatory pressure, innovation capabilities, and legitimation capabilities.

Hypothesis 4:Regulatory pressure will positively moderate the interaction effect of a new venture's product innovation capabilities and legitimation capabilities on its performance.

\section{Methods \\ Sample}

The hypotheses were tested with multiple regression analysis of data obtained from a large-scale mail survey 
to executives of new ventures in a broad cross-section of manufacturing industries in the United States. The cross-sectional sampling framework was chosen in order to test the impact of different environmental contexts. The sample was drawn randomly in each of the selected industry groups from a commercially available list. Criteria for selecting new ventures were: (1) eight years or younger; (2) independent; and (3) USbased ventures that operate in selected industries. Selected eight industries include: (1) wood product manufacturing, (2) commodity chemical manufacturing, (3) pharmaceutical and medicine manufacturing, (4) machinery manufacturing, (5) communications equipment manufacturing, (6) semiconductor and other electronic component manufacturing, (7) navigational, measuring, electromedical, and control instruments manufacturing, and (8) medical equipment and supplies manufacturing. These industries were chosen because they were assumed to exhibit a variety of institutional as well as competitive characteristics.

The company list, which contains mailing addresses and the names of top management, was obtained from Zapdata.com, the Internet service of $D \& B \otimes$ Sales \& Marketing Solution. Dun \& Bradstreet (D\&B) database has been widely used in cross-sectional studies as one of the very few available for a cross-sectional national sampling frame. We mailed two waves of surveys, and followed up with post cards. We excluded firms that were out of the scope of this study or violated random sampling criteria (e.g., D\&B's practice to reset company age when ownership changed caused accuracy issues in terms of defining young companies-those included 129 companies who were older than 8 years, 44 service providers, 19 subsidiaries, and several companies for which the owners of the selected firms work as employee or consultant) as well as those with missing data from our final sample. The sample size for the two models (growth and profitability as dependent variables) was 293 and 288, respectively. Non-response bias was evaluated using a non-parametric test (KolmogorovSmirnov) and Independent-Samples T-test to compare earlier and latter respondents. No differences were observed.

The average firms in the sample were 3 to 5 years old, had 2 to 4 employees, less than $\$ 1$ million revenues, operated as a private corporation in one of various manufacturing industries, located in one of the states in the United States (see Table 1).

\section{Table 1. The Sample}




\begin{tabular}{|c|c|c|c|}
\hline & \multicolumn{3}{|c|}{ Sample } \\
\hline & & $\mathrm{N}=$ & 300 \\
\hline & & $\begin{array}{l}\text { Number of } \\
\text { firms }\end{array}$ & Percent \\
\hline \multirow[t]{4}{*}{ Company age } & $0-2$ & 57 & $19.0 \%$ \\
\hline & $3-5$ & 33 & $44.3 \%$ \\
\hline & $6-8$ & 10 & $36.7 \%$ \\
\hline & Total & 300 & $100.0 \%$ \\
\hline \multirow[t]{8}{*}{ Number of employees } & $0-1$ & 45 & $15.0 \%$ \\
\hline & $2-4$ & 92 & $30.7 \%$ \\
\hline & $5-9$ & 54 & $18.0 \%$ \\
\hline & $10-24$ & 53 & $17.7 \%$ \\
\hline & $25-49$ & 35 & $11.7 \%$ \\
\hline & $50-99$ & 11 & $3.7 \%$ \\
\hline & $>=100$ & 10 & $3.3 \%$ \\
\hline & Total & 300 & $100.0 \%$ \\
\hline Annual revenue & $<0.9$ & 142 & $47.3 \%$ \\
\hline \multirow[t]{7}{*}{$(\$ M M)$} & $1.0-2.4$ & 57 & $19.0 \%$ \\
\hline & $2.5-4.9$ & 28 & $9.3 \%$ \\
\hline & $5.0-9.9$ & 16 & $5.3 \%$ \\
\hline & $10.0-24.9$ & 13 & $4.3 \%$ \\
\hline & $25.0-49.9$ & 5 & $1.7 \%$ \\
\hline & $>50.0$ & 4 & $1.3 \%$ \\
\hline & Total & 265 & $88.3 \%$ \\
\hline \multirow[t]{3}{*}{ Ownership } & Private & 297 & $99.0 \%$ \\
\hline & Public & 3 & $1.0 \%$ \\
\hline & Total & 300 & $100.0 \%$ \\
\hline \multirow[t]{6}{*}{ Legal structure } & Sole proprietorship & 50 & $16.7 \%$ \\
\hline & Partnership & 13 & $4.3 \%$ \\
\hline & LLC & 35 & $11.7 \%$ \\
\hline & Corporation & 200 & $66.7 \%$ \\
\hline & Other & 2 & $0.7 \%$ \\
\hline & Total & 300 & $100.0 \%$ \\
\hline \multirow[t]{13}{*}{ Region } & California & 44 & $14.7 \%$ \\
\hline & New England & 18 & $6.0 \%$ \\
\hline & Metro & 32 & $10.7 \%$ \\
\hline & Southeast & 40 & $13.3 \%$ \\
\hline & Mideast & 56 & $18.7 \%$ \\
\hline & Northwest & 18 & $6.0 \%$ \\
\hline & Texas & 22 & $7.3 \%$ \\
\hline & North Central & 31 & $10.3 \%$ \\
\hline & Colorado & 2 & $0.7 \%$ \\
\hline & Southwest & 23 & $7.7 \%$ \\
\hline & $\mathrm{AK} / \mathrm{HI} / \mathrm{PR}$ & 3 & $1.0 \%$ \\
\hline & South Central & 11 & $3.7 \%$ \\
\hline & Total & 300 & $100.0 \%$ \\
\hline
\end{tabular}

analysis further validated this finding with reasonably good fit indices to the overall model ${ }^{3}$ \#footnote3) (NFI = $0.89, \mathrm{NNFI}=0.94, \mathrm{CFI}=0.95, \mathrm{SRMR}=0.050, \mathrm{RMSEA}$ $=0.051$ ), all construct reliability estimates were in excess of .70 and variance extracted (a test of discriminant validity) was in excess of .50 . These results suggested that the measures adequately represent the constructs in the model. Consequently, by taking the means of their indicators, the composite measures of constructs were created for use in the subsequent multivariate regression analyses. Table 2 summarizes the scale reliabilities and item factor loadings; the Appendix gives the detailed texts of the items.

Table 2. Scale Reliability and Item Factor loadings $^{a}$

\section{Measures}

Measures were developed in several stages. In the first stage, based on the defined constructs, tentative measures were either borrowed from the literature or newly developed. In the second stage, interviews were conducted for item refinement. Incorporating feedbacks from the executives of four new ventures, the measurement items as well as the design of the questionnaire were refined. Then, a pretest was conducted with executives of 31 companies, mostly IT companies in $\mathrm{OHIO}$, and the measures were further refined.

Exploratory factor analyses confirmed the anticipated factor structure of measures. Confirmatory factor 


\begin{tabular}{|c|c|c|c|c|c|c|c|c|}
\hline Item/Factor & 1 & 2 & 3 & 4 & 5 & 6 & 7 & 8 \\
\hline 1. Radicality & & & & & & & & \\
\hline $\begin{array}{l}\text { PRA1 } \\
\text { PRA2 }\end{array}$ & .79 & & & & & & & \\
\hline $\begin{array}{l}\text { PRA3 } \\
\text { PRA3 }\end{array}$ & .55 & & & & & & & \\
\hline 2. Product breadth & & & & & & & & \\
\hline PBR1 & & .80 & & & & & & \\
\hline PBR2 & & .92 & & & & & & \\
\hline & & .92 & & & & & & \\
\hline 3. Product advantage & & & & & & & & \\
\hline $\begin{array}{l}\text { PAD1 } \\
\text { PAD2 }\end{array}$ & & & .71 & & & & & \\
\hline 4. Internal legitimacy of innovation & & & & & & & & \\
\hline INC1 & & & & .59 & & & & \\
\hline $\mathrm{INC} 2$ & & & & .73 & & & & \\
\hline INC3 & & & & .63 & & & & \\
\hline 5. Media firm legitimation & & & & & & & & \\
\hline LMF1 & & & & & .89 & & & \\
\hline LMF2 & & & & & .88 & & & \\
\hline LMF3 & & & & & .90 & & & \\
\hline 6. Endorsement & & & & & & & & \\
\hline LEN1 & & & & & & .59 & & \\
\hline LEN2 & & & & & & .97 & & \\
\hline LEN3 & & & & & & .54 & & \\
\hline 7. Regulatory pressure & & & & & & & & \\
\hline INP1 & & & & & & & .84 & \\
\hline INP2 & & & & & & & .87 & \\
\hline INP3 & & & & & & & .78 & \\
\hline INP4 & & & & & & & .68 & \\
\hline INP5 & & & & & & & .73 & \\
\hline $\begin{array}{l}\text { 8. Internal marketing resources } \\
\text { IMR1 }\end{array}$ & & & & & & & & \\
\hline $\begin{array}{l}\text { IMR1 } \\
\text { IMR2 }\end{array}$ & & & & & & & & .88 \\
\hline IMR3 & & & & & & & & .88 \\
\hline Alpha & .82 & .90 & .81 & .74 & .91 & .78 & .88 & .81 \\
\hline
\end{tabular}

${ }^{a}$ The extraction method was principal axis factoring. The rotation method was Promax with Kaiser normalization. The cutoff point was .30 .

Dependent variables.Measuring new venture performance presents special challenges. First, privately held new ventures have no obligation to disclose performance information and they are often reluctant to do so (Sandberg \& Hofer, 1987). Second, the trade-offs that might exist between growth and profitability make the construct of new venture performance complex (Brush \& VanderWerf, 1992). Third, new ventures' financial performances often show great yearly fluctuations. Hence, the combination of multiple approaches was used to estimate new venture performance: measuring performance in terms of growth and profitability, asking relative values of performance to competitors in categories, and smoothing out values in the use of 3-year averages. Growth was assessed in three items: average annual growth in the number of employees, average annual sales growth, and average market share growth in sales in the last three years. Profitability was assessed by three items: average annual return on sales (ROS), average annual return on assets (ROA), and average annual return on equity $(\mathrm{ROE})$ in the last three years. Respondents were asked to rate their company's performance in comparison to their major competitors. Prior studies indicate that these subjective measures of performance can be consistent with objective measures (Dess \& Robinson, 1984; Dess,
Lumpkin, \& Covin, 1997).

\section{Independent}

and moderating variables.Product innovation capabilities were assessed across three variables-namely, radicality, product breadth, and product advantage. The measurements of these variables were employed from scales used by prior work (Chandy \& Tellis, 1998; Covin, Slevin, Heeley, \& Michael, 2000; Song \& Parry, 1997; Zahra \& Bogner, 2000 ) and rearranged to fit with a theoretical foundation of this study. Radicality questions asked about a venture's ability to introduce radically new products to markets ahead of competitors. Product breadth questions aimed to capture a new venture's ability to offer a large number of new products and product modifications. Product advantage questions asked about relative product superiority in comparison with competitors in terms of product performance and meeting customer needs.

Legitimation capabilities consist of three major variables-namely, internal legitimacy of innovation, media firm legitimation, and endorsement. The questions for internal legitimacy of innovation were also developed from prior work (Covin \& Slevin, 1989; Deshpande, Farley, \& Webster, 1993; Jassawalla \& Sashittal, 2002). Media firm legitimation was measured by the degree of positive media coverage of the firm and its products. Endorsement was measured by items that asked about the relational endorsement from prominent individuals and organizations. These measures were newly developed.

Regulatory pressure was assessed according to the degree of industry-level regulatory pressure. The five items were developed from scales used by Meznar and Nigh (1995). Regulatory pressure questions aimed to capture pressures from regulatory institutions in the main industry of the firm. In order to transform the perceived regulatory pressure at the individual level into the industry-level regulatory pressure, a new variable was created taking the mean of regulatory pressure of individual respondents in each industry (see Table 3). One-way ANOVA test indicated that the mean differences across industries are significant $(F=11.46$, $p=.000)$.

Table 3. Industry-Level Regulatory Pressure 


\begin{tabular}{clrc}
\hline Rank & Industry & N & Mean \\
\hline 1 & Pharmaceutical and medicine manufacturing & 38 & 4.13 \\
2 & Medical equipment and supplies manufacturing & 43 & 3.96 \\
3 & Commodity chemical manufacturing & 36 & 3.37 \\
4 & Communications equipment manufacturing & 35 & 3.20 \\
5 & Other manufacturing & 31 & 3.12 \\
6 & Navigational, measuring, electromedical, and control instruments & 30 & 2.92 \\
7 & manufacturing & 34 & 2.72 \\
8 & Semiconductor and other electronic component manufacturing & 17 & 2.64 \\
9 & Machinery manufacturing & 36 & 2.57 \\
\hline Total \& Average & 300 & 3.18 \\
\hline
\end{tabular}

Control variables. We included several control variables in the model since many other factors are likely to influence new venture performance.

Firm size is likely to be related to new venture performance because of larger resources as well as organizational power, which determines the degree of social pressure that the firm can control (Pfeffer and Salancik, 1978). The total number of employees is used to control for the influence of size on hypothesized relationships.

Internal marketing resources are measured by a relative level of advertising/promotional expenditures and strength of sales force and distribution channels. Marketing resources enable firms to profit from innovation by reaching out to potential customers and winning them over competitors (Teece, 1986) and facilitate the effects of innovation by informing market needs and demands (Dierickx \& Cool, 1989). Hence, marketing resources are likely to have a strong impact on profiting from product innovation (Teece, 1986). Since the focus of this study is on the higher level capabilities regarding product innovation and legitimation rather than individual functional capabilities or resources, this variable was used as a control.

Although the industry-level regulatory pressure variable is expected to capture some of the industry characteristics, the degree of regulatory pressure does not represent all differences by industry. Hence, eight dummy variables were created to control for possible performance differences by industry. Three industry dummy variables that demonstrated significance in the regression analyses were kept as controls.

\section{Data Analysis}

We used a moderated hierarchical regression analysis to examine the hypothesized relationships. The control variables, followed by the independent variables and the two- and three-way interaction terms were introduced sequentially by group into the regression equation. Prior to the creation of interaction terms, all variables except industry dummies were standardized using the $z$ transformation to reduce the problem of multicollinearity ${ }^{4}$

(https://eiexchange.com/create.php?id=27\#footnote4) We also examined data prior to regression analysis, testing the assumption of multivariate analysis and influential outliers. As a result, two cases were eliminated as influential outliers in order to ensure a representative sample of the general population of the study. There was no evidence of the violation of the assumption of multivariate analysis or multicollinearity. The nature of interaction effects found in the regression analyses were examined by the approach described by Aiken and West (1991).

\section{Results}

Descriptive statistics and correlations are reported in Table 4, and the results of regression analyses are reported in Table 5 for growth (as the dependent variable) and in Table 6 for profitability (as the dependent variable).

Table 4. Means, Standard Deviations, and Correlations

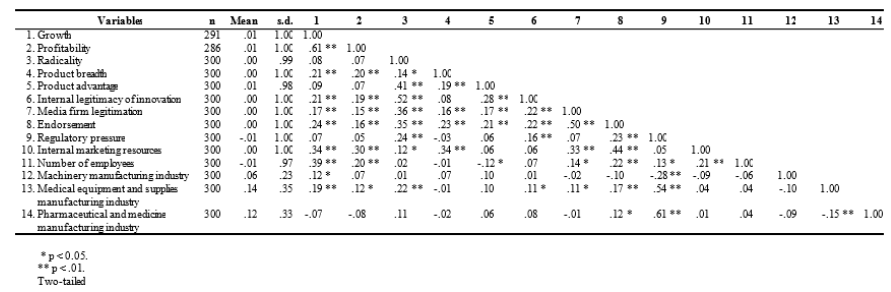

Table 5. Regression Results for Growth ${ }^{\mathrm{a}}$ 


\begin{tabular}{|c|c|c|c|}
\hline Variables & Model 1 & Model 2 & Model 3 \\
\hline (Constant) & -.09 & -.10 & -.08 \\
\hline Number of employees & $.34 * * *$ & $.34 * * *$ & $.38 * 8 *$ \\
\hline Internal marketing resources & $.28 * 8 *$ & $.23 * * *$ & $.20 * * *$ \\
\hline Machinery manufacturing industry & $.78 * 8 *$ & $.70 * 8$ & $.80 * * *$ \\
\hline Medical equipment and supplies manufacturing industry & $.54 * * *$ & $.60 *$ & $.58 *$ \\
\hline Pharmaceutical and medicine manufacturing industry & -.15 & -.08 & -.26 \\
\hline Radicality & & $-.13 *$ & $-.16^{* *}$ \\
\hline Product breadth & & $.12 *$ & $.12 *$ \\
\hline Product advantage & & .05 & $.12 *$ \\
\hline Internal legitimacy of innovation & & $.19 * *$ & $.21 * * *$ \\
\hline Media firm legitimation & & .00 & .06 \\
\hline Endorsement & & .03 & .06 \\
\hline Industry-level regulatory pressure & & -.04 & -.03 \\
\hline Internal legitimacy of innovation $x$ Product breadth & & & $.10^{*}$ \\
\hline Media firm legitimation $\times$ Product breadth & & & .02 \\
\hline Endorsement $\mathrm{x}$ Product advantage & & & $-.10 *$ \\
\hline Industry-level regulatory pressure $\mathrm{x}$ Radicality & & & $-.10^{\circ}$ \\
\hline Industry-level regulatory pressure $\mathrm{x}$ Product breadth & & & -.01 \\
\hline Industry-level regulatory pressure $\mathrm{x}$ Product advantage & & & $.19 * 8$ \\
\hline Industry-level regulatory pressure $\mathrm{x}$ Media firm legitimation & & & .02 \\
\hline Industry-level regulatory pressure $\mathrm{x}$ Endorsement & & & .06 \\
\hline $\begin{array}{l}\text { Industry-level regulatory pressure } \mathrm{x} \text { Product breadth } \mathrm{x} \text { media } \\
\text { firm legitimation }\end{array}$ & & & $.16^{* *}$ \\
\hline $\begin{array}{l}\text { Industry-level regulatory pressure } \mathrm{x} \text { Product advantage } \mathrm{x} \\
\text { Endorsement }\end{array}$ & & & $-.22 * * *$ \\
\hline $\mathrm{R}^{2}$ & .29 & .33 & .40 \\
\hline Adjusted $R^{2}$ & .27 & .30 & .35 \\
\hline $\mathrm{F}$ & $22.94 * 8 *$ & $11.58 * * *$ & $8.17 * 8 *$ \\
\hline
\end{tabular}

${ }^{2} \mathrm{~N}=291$; Unstandardized regression coefficients are reported.

${ }^{\top} p<.10$

${ }^{*} \mathrm{p}<.05$

$* * * p<.001$

Table 6. Regression Results for Profitability ${ }^{a}$

\begin{tabular}{|c|c|c|c|}
\hline Variables & Model 1 & Model 2 & Model 3 \\
\hline (Constant) & -.04 & .05 & .05 \\
\hline Number of employees & $.14 * 8$ & $.13 *$ & $.16 * 8$ \\
\hline Internal marketing resources & $.28 * * *$ & $.25 * 8$ & $.22 * *$ \\
\hline Machinery manufacturing industry & $.49 \top^{\top}$ & $.49+$ & $.55{ }^{\circ}$ \\
\hline Medical equipment and supplies manufacturing industry & $.31 \uparrow$ & .02 & -.09 \\
\hline Pharmaceutical and medicine manufacturing industry & -.22 & $-.59+$ & $-.80 *$ \\
\hline Radicality & & -.11 & $-.12+$ \\
\hline Product breadth & & $.11 \uparrow$ & $.13 *$ \\
\hline Product advantage & & .03 & .07 \\
\hline Internal legitimacy of innovation & & $.20 * *$ & $.23 * * *$ \\
\hline Media firm legitimation & & .04 & .06 \\
\hline Endorsement & & -.04 & .00 \\
\hline Industry-level regulatory pressure & & .17 & .21 \\
\hline Internal legitimacy of innovation $x$ Product breadth & & & .08 \\
\hline Media firm legitimation $x$ Product breadth & & & $.12 *$ \\
\hline Endorsement $\mathrm{x}$ Product advantage & & & -.09 \\
\hline Industry-level regulatory pressure $\mathrm{x}$ Radicality & & & -.07 \\
\hline Industry-level regulatory pressure $\mathrm{x}$ Product breadth & & & -.03 \\
\hline Industry-level regulatory pressure $\mathrm{x}$ Product advantage & & & $.14 *$ \\
\hline Industry-level regulatory pressure $\mathrm{x}$ Media firm legitimation & & & .05 \\
\hline Industry-level regulatory pressure $\mathrm{x}$ Endorsement & & & .10 \\
\hline $\begin{array}{l}\text { Industry-level regulatory pressure } \mathrm{x} \text { Product breadth } \mathrm{x} \text { media } \\
\text { firm legitimation }\end{array}$ & & & .04 \\
\hline $\begin{array}{l}\text { Industry-level regulatory pressure } \mathrm{x} \text { Product advantage } \mathrm{x} \\
\text { Endorsement }\end{array}$ & & & $-.12 \uparrow$ \\
\hline $\mathrm{R}^{2}$ & .14 & .19 & .23 \\
\hline Adjusted $\mathrm{R}^{2}$ & .12 & .15 & .17 \\
\hline $\mathrm{F}$ & $8.95 * * *$ & $5.23 * * *$ & $3.62 * * *$ \\
\hline
\end{tabular}

Growth. As Table 5 shows, in Model 1, the coefficients for the number of employees, internal marketing resources, and two industry dummies were significant and positive. Model 2 examined the direct effects of independent variables. The coefficients for product breadth $(b=.12, p=.026)$ and internal legitimacy of innovation $(b=.19, p=.001)$ were significant and positive. The coefficient for radicality was significant and negative $(b=-.13, p=.040)$ and other variables were not significant predictors.

Next, we introduced two- and three-way interaction terms into the model (Model 3). Among the two-way interactions, the interaction between internal legitimacy of innovation and product breadth was significant and positive $(b=.10, p=.029)$, supporting Hypothesis 1 . The result suggested that there is a synergistic effect between product breadth and internal legitimacy of innovation. However, the interaction between endorsement and product advantage was significant but negative $(b=-.10, p=.029)$. These results combined indicated that product innovation capabilities lead to greater performance but is contingent on the degree of internal vs. external legitimation capabilities.

The interaction between regulatory pressure and product advantage was significant and positive $(b=.19$, $p=.002$ ) supporting Hypothesis 3 . However, the interaction between regulatory pressure and radicality was significant but negative $(b=-.10, p=.070)$ indicating that the negative effect of radicality is stronger 
when regulatory pressure is high. These results combined demonstrated that product innovation capabilities are important weapon for new ventures in environments with high regulatory pressure, but that ventures cannot get too far from the norm. The significant two-way interaction effects mentioned above are plotted in figures $2 \mathrm{a}, 2 \mathrm{~b}, 2 \mathrm{c}$, and $2 \mathrm{~d}$, respectively.

\section{Figure 2. Two-Predictor Interaction Effects}

2a. Internal legitimacy of innovation and product breadth on growth

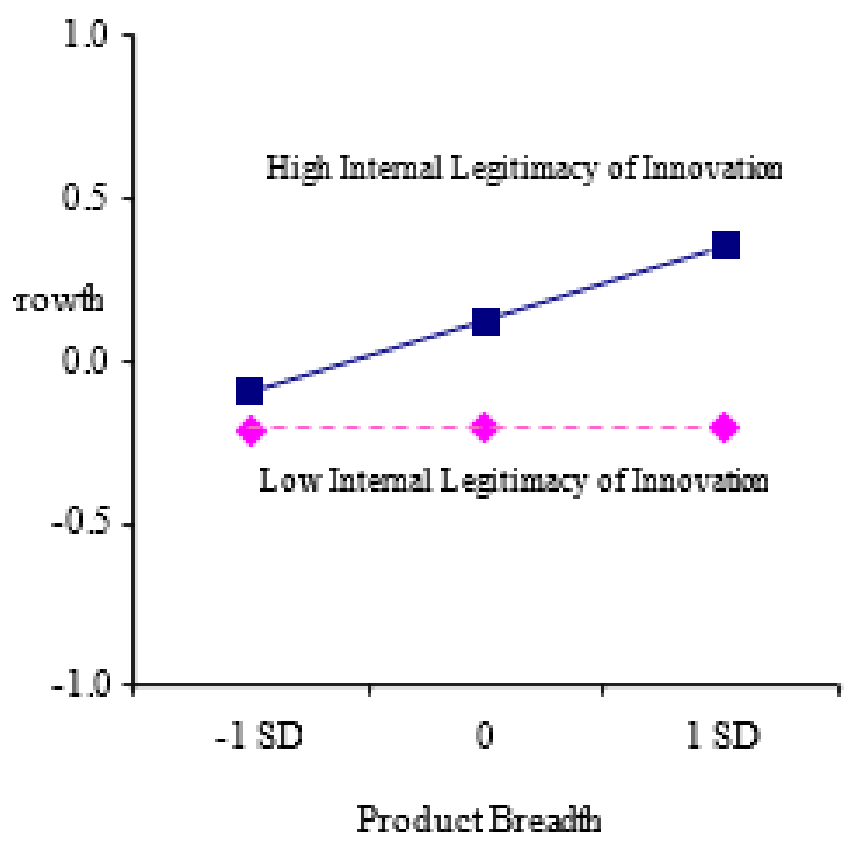

2b. Endorsement and product advantage on growth

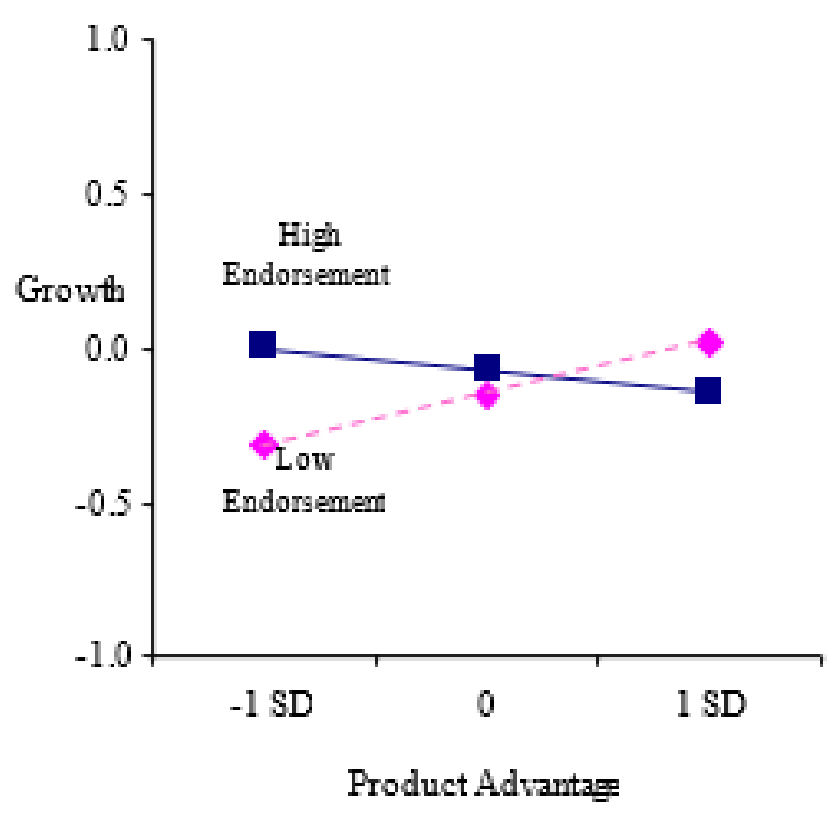

2c.Industry-level regulatory pressure and product advantage on growth

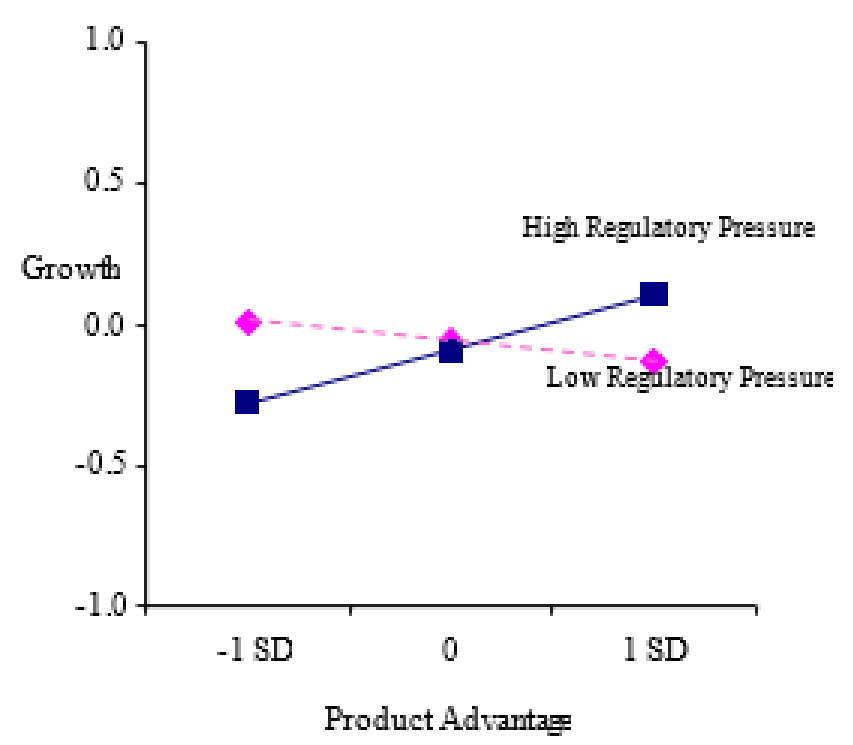

$2 d$.Industry-level regulatory pressure and radicality on growth 


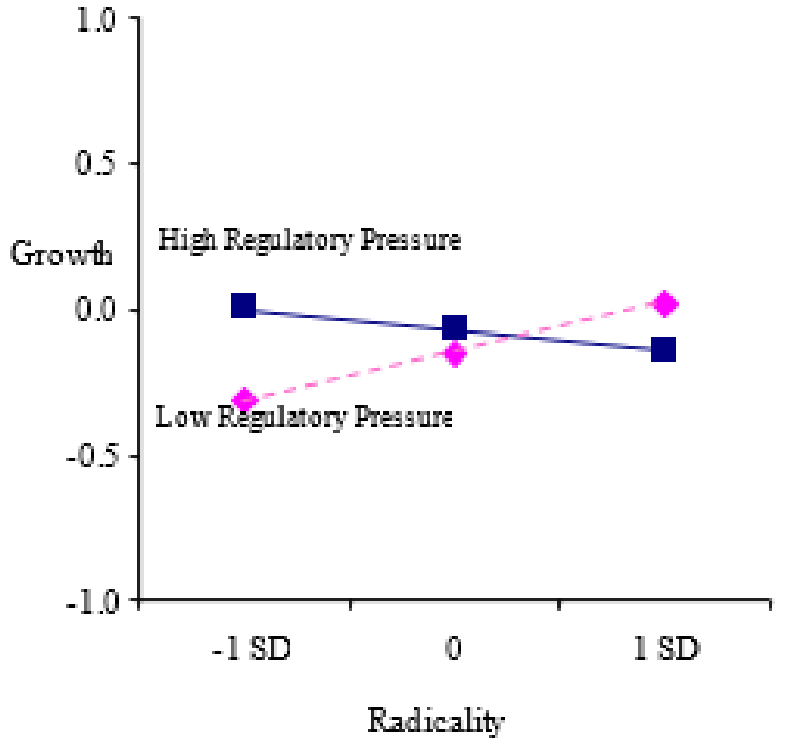

The three-way interaction among regulatory pressure, product advantage, and endorsement exhibited a significant relationship with growth $(b=-.22, p=.000)$. As Figure $3 a$ graphically illustrates, when regulatory pressure is high and endorsement is low, product advantage is significantly and positively associated with growth $(b=.63, p=.000)$, but not when regulatory pressure is high and endorsement is high. When regulatory pressure is low and endorsement is low, product advantage is significantly and negatively related to growth $(b=-.19, p=.037)$, but not when regulatory pressure is low and endorsement is high. Overall, the result shows that relationship between product advantage and growth is contingent upon both endorsement and regulatory pressure. In a high regulatory pressure environment, a new venture with low product advantage is severely disadvantaged but this disadvantage can be partially mitigated by obtaining high endorsement. However, when product advantage is high, growth is higher without endorsement than with high endorsement. In contrast, in low pressure environments, without endorsement, product advantage is negatively associated with growth. Firm growth seems attainable with low product advantage but when product advantage is high, growth needs support from endorsement.

\section{Figure 3. Three-Predictor Interaction Effects}

3a. Industry-level regulatory pressure, product advantage, and endorsement on growth
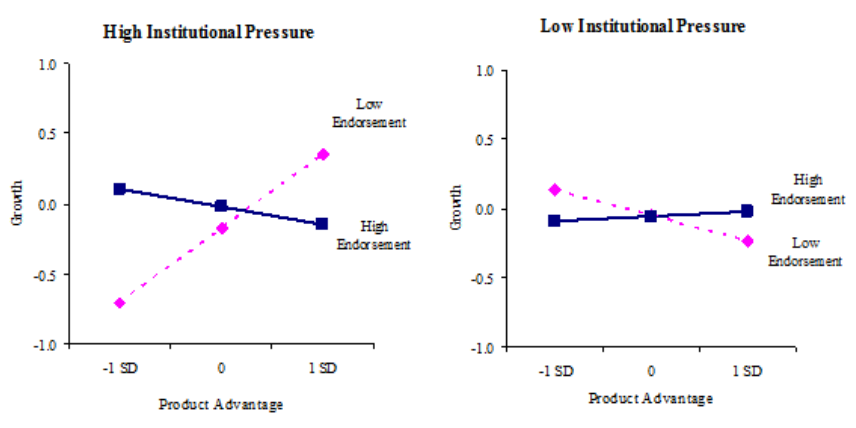

3b.Industry-level regulatory pressure, product breadth, and media firm legitimation on growth
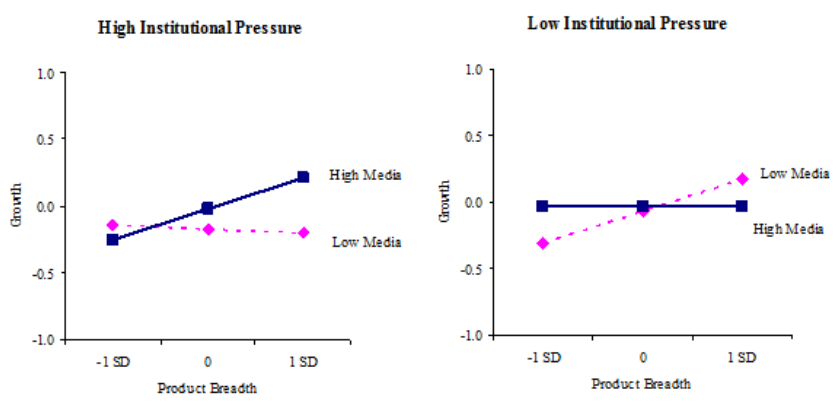

3c.Industry-level regulatory pressure, product advantage, and endorsement on profitability
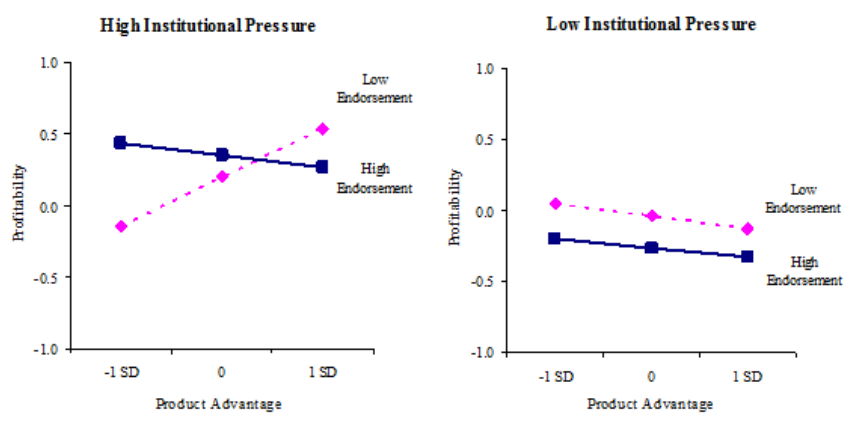

The three-way interaction among regulatory pressure, product breadth, and media firm legitimation was also a significant predictor of growth $(b=.16, p=.002)$. As depicted in Figure $3 b$, when regulatory pressure is high and media firm legitimation is high, product breadth is significantly and positively associated with growth $(b=$ $.30, p=.006$ ), but not when regulatory pressure is high and media legitimation is low. When regulatory pressure is low and media firm legitimation is low, product breadth is significantly and positively related to growth ( $b=.27, p=.003$ ), but not when regulatory pressure is low and media firm legitimation is high. As seen in these graphs, the pattern of the interaction effect is different from the former one. In this case, in a high regulatory pressure environment, product breadth is not related to 
growth without media firm legitimation. Achieving firm growth with broad product lines in environments with high regulatory pressure is facilitated by positive media coverage. In contrast, in a low regulatory pressure environment, a new venture with narrow product lines is disadvantaged but this disadvantage can be mitigated by having high media coverage. However, when product lines are broad, firm growth is higher without media coverage than with media coverage. These three-way interaction effects partially support our Hypothesis 4, but more importantly they highlight a much more subtle and complex relationship among innovation and legitimation capabilities, regulatory pressure, and venture performance.

Profitability. With the same predictor variables, the relationships with profitability as the dependent variable were examined. As seen in Table 6, similar relationships found in the growth models were seen in the profitability models, although the levels of significance were weaker than those in the growth models. In Model 1, the coefficients for the number of employees and internal marketing resources were positive. In Model 2, internal legitimacy of innovation $(b=.20, p=.002)$ and product breadth $(b=.11, p=.072)$ showed significant and positive associations with profitability. In Model 3, the interaction term between product breadth and media firm legitimation was significant and positive $(b=.12, p$ $=.038$ ), indicating that there are synergies between product breadth and media firm legitimation. The interaction between product advantage and regulatory pressure was also significant $(b=.14, p=.036)$ and the three-way interaction among product advantage, endorsement, and regulatory pressure was marginally significant $(b=-.12, p=.095)$. As seen in Figure $3 c$, the pattern of the three-way interaction effect was similar to those with the growth model. When regulatory pressure is high and endorsement is low, product advantage is significantly and positively associated with profitability ( $b=.43, p=.002)$, but not when regulatory pressure is high and endorsement is high. When regulatory pressure is low and endorsement is low, product advantage is not significantly related to profitability regardless of the degree of endorsement. The results relative to the hypotheses are summarized in Table 7.

\section{Table 7. Summary of Hypotheses and Findings}

H1. A new venture's legitimation capabilities positively moderate the relationship between its product innovation capabilities and performance.

\begin{tabular}{|l|l|l|}
\hline \multirow{2}{*}{ Legitimation } & \multicolumn{1}{|c|}{ Growth } & \multicolumn{1}{|c|}{ New Venture Performance } \\
\cline { 2 - 3 } & \multicolumn{1}{|c|}{ Profitability } \\
\hline $\begin{array}{l}\text { Intermal } \\
\text { legitimacy of } \\
\text { innovation }\end{array}$ & Supported with product breadth. & Not supported. \\
\hline $\begin{array}{l}\text { Media firm } \\
\text { legitimation }\end{array}$ & Not supported. & Supported with product breadth. \\
\hline Endorsement & Not supported. The effect was negative. & Not supported. \\
\hline
\end{tabular}

H2. Regulatory pressure will positively moderate the relationship between a new venture's legitimation capabilities and its performance.

\begin{tabular}{|l|l|l|}
\hline Legitimation & \multicolumn{3}{|c|}{ New Venture Performance } \\
\cline { 2 - 4 } & Growth & Profitability \\
\hline $\begin{array}{l}\text { Media firm } \\
\text { legitimation }\end{array}$ & Not supported. & Not supported. \\
\hline Endorsement & Not supported. & Not supported. \\
\hline
\end{tabular}

H3. Regulatory pressure will positively moderate the relationship between a new venture's product innovation capabilities and its performance.

\begin{tabular}{|l|l|l|}
\hline \multirow{2}{*}{$\begin{array}{l}\text { Product } \\
\text { innovation }\end{array}$} & \multicolumn{2}{|c|}{ Nownth } \\
\cline { 2 - 3 } Radicality & $\begin{array}{l}\text { Not supported. The effect was negative (marginal } \\
\text { significance). }\end{array}$ & Not supported. \\
\hline $\begin{array}{l}\text { Product } \\
\text { breadth }\end{array}$ & Not supported. & Not supported. \\
\hline $\begin{array}{l}\text { Product } \\
\text { advantage }\end{array}$ & Supported. & Supported. \\
\hline
\end{tabular}

H4. Regulatory pressure will positively moderate the interaction effects of a new venture's product innovation capabilities and legitimation capabilities on its performance.

\begin{tabular}{|l|l|l|}
\hline Interactions & \multicolumn{2}{|c|}{ Growth } \\
\cline { 2 - 3 } & \multicolumn{2}{|c|}{ Genture Performance } \\
\hline $\begin{array}{l}\text { Regulatory pressure } \mathrm{x} \\
\text { Product breadth } \mathrm{x} \text { Media } \\
\text { firm legitimatility }\end{array}$ & Supported. & Not supported. \\
\hline $\begin{array}{l}\text { Regulatory pressure } \mathrm{x} \\
\begin{array}{l}\text { Product advantage } \mathrm{x} \\
\text { Endorsement }\end{array}\end{array}$ & Supported. & \\
\hline
\end{tabular}

\section{Discussion Contributions}

The empirical findings support our study's central proposition that a new venture's product innovation capabilities and legitimation capabilities jointly affect organizational performance and that those effects are 
contingent upon the level of regulatory pressure posed by the external environment. The interactions paint a much more complex picture than the model we theorized.

As we report in Table 3, new ventures in some industries are more strongly confronted by regulatory forces than those in other industries. Examples are those in the pharmaceutical industry where many procedures and output qualities are subject to complying with regulations. In contrast, it was evidenced that in the wood manufacturing industry, for example, regulatory pressures are weak. Since small, young firms are highly dependent on environments for resources, and are typically susceptible to environmental conditions (Aldrich \& Martinez, 2001) it makes sense that the degree of regulatory pressure imposed by the external environment is likely to have an important impact on entrepreneurial activities and outcomes.

Our results show that in a high regulatory pressure environment, endorsement exhibits a positive impact on the performance of new ventures that do not have sufficient abilities to introduce superior products. However, when new ventures are able to offer superior products, they are likely to achieve higher growth and profitability without endorsement than with high endorsement. A possible explanation for this result is that product advantage has a power to gain acceptance from the external environment by itself in high regulatory pressure industries. This suggests that a venture which is able to develop the capabilities to create product advantage in the face of pressure from regulators, incumbents, and other actors in a high regulatory pressure environment send legitimating signals to their constituents. In these circumstances legitimation capabilities appear to be redundant and to only provide value if the venture is unable to create product advantage. Even then these capabilities are only able to mitigate the impacts of not having created product advantage. In a low regulatory pressure environment, the capabilities to create product advantage provides no improvement in growth or profitability, but rather leads to underperformance which is only partially mitigated by the development of legitimation capabilities.

These are important findings for entrepreneurs, entrepreneurship scholars, and organizational scholars. Given that ventures are institutionally embedded, it is important for us to gain insight into the relationship between the regulatory pressures faced by a venture and the capabilities that lead to growth and profitability. As noted by Ethiraj, Kale, Krishnan, and Singh (2005), building capabilities requires significant and often, irreversible commitment of real resources, both financial and managerial. Decisions about which capabilities to acquire or build require due diligence in the analysis of costs and benefits. This is particularly important in resource constrained ventures. Our results suggest that the regulatory environment has an important impact on the ability of different capabilities to contribute to enhancing performance and the returns ventures can expect from investing in those capabilities.

These findings provide important insight into when institutional entrepreneurship and strategically seeking legitimacy are likely to be beneficial and when they are not. A number of studies have found a link between legitimating actions, such as endorsements and certifications (e.g., Baum \& Oliver, 1991; Rao, 1994; Sine, David, \& Mitsuhashi, 2007; Stuart et al., 1999) but what has been missing to date is a study across industries with varying degrees of regulatory pressure. These studies all began with the assumption that the organizational activities are institutionally embedded, but they have not fully examined how variation in that institutional environment changes the benefits ventures receive from organizational activities, such as seeking endorsements and generating media coverage. While disadvantaged new ventures need help from endorsement, for those who have sufficient ability of product advantage, endorsement is unnecessary, and the costs of endorsement offset its benefits. The existence of such costs has been discussed in the alliance literature. Examples are those costs in preventing risks of exploitation by larger partners and synchronizing collaboration among independent firms (Alvarez \& Barney, 2001; Williamson, 1991).

The study found different patterns of joint moderating effects on the product breadth-growth relationship. The result indicated that in an environment in which regulatory pressure is high, firm growth with broad product lines is not attainable without support from media endorsements. It could be that in a high pressure environment, in contrast to product advantage, product breadth by itself does not have legitimation power, and hence ventures with broad product lines require the help from external endorsements provided by positive media coverage. In contrast, in an environment in which regulatory pressure is low, the opposite mechanism was observed. Ventures with broad product lines received 
little benefit from media endorsements and the best performing ventures in this environment had broad product lines and little media coverage. The result shows that firm growth with broad product lines is attainable without strategically seeking legitimacy. However, in a low pressure environment, ventures with narrow product lines are disadvantaged but are able to partially mitigate this disadvantage by obtaining positive media coverage.

Another important finding is that internal legitimacy of innovation has a significant and positive impact on new venture performance. Relying on strangers and lacking stable routines (Stinchcombe, 1965), one of the challenges for entrepreneurs is to generate collective purpose, commitment, and energy in an organization (Pettigrew, 1979). Creating shared beliefs, norms, and values among participants around innovation is important for transforming individual drives into cohesive activities that contribute to firm success. The result of the moderating effect with product breadth further suggests that achieving firm growth with broad product lines requires legitimation of innovation. The concurrent introduction of broad lines of products involves numerous and varied activities, increasing the complexity of the task environment, and enhancing the need for shared beliefs, norms, and values to guide and coordinate the disparate activities, required to bring a broad innovative product line to fruition in a new venture.

Overall, our findings suggest that the regulatory pressure of the environment in which the new venture operates conditions the ability of a venture to earn returns from its investment in the capability building and maintenance, but that the interaction among these forces is subtle and complex. When new ventures are disadvantaged due to limited product innovation capabilities crucial in their contexts, they can offset some of their weakness and increase performance by obtaining relational or media endorsement. However, when new ventures have sufficient product innovation capabilities that generate product advantages, unnecessarily seeking endorsements can detract from performance.

This paper makes a much needed contribution to the fields of entrepreneurship and organizational studies by bringing the concept of the regulatory pressure in a ventures environment to the forefront. It provides a tool for measuring that pressure, and it begins the process of examining the complex role regulatory pressure plays in a venture's growth and performance. It further adds to our understanding of organizational capabilities, but considering the role of context, in this case regulatory pressure, on the contribution of two different types of capabilities, legitimation and innovation, on the relationship between these capabilities and venture growth and profitability. We hope that this paper will encourage others to examine how variations in institutional contexts impact organizational activities and outcomes.

\section{Limitations and Future Research}

This study, like any study, has limitations. First, since new venture performance is an outcome of a process that occurs over the time, we acknowledge that longitudinal research is more desirable for more accurately examining the determinants of new venture performance. Second, the sample includes only surviving new ventures, relying on self-reported data. This may pose such potential problems as selection bias, common method bias, and subjective judgment by respondents. An ideal sample would require all types of new ventures from successful to failed firms, using subjective and objective data in combination. Third, the empirical results derived from a sample of U.S. new ventures may raise the concern that findings are countryspecific. One can argue that in other countries, different competitive and institutional mechanisms exist and affect new venture success prospects in different ways. Comparative study across multiple countries will give us more insights about concurrent effects of competitive and institutional factors on entrepreneurial outcomes. Despite these limitations we believe that this study expands our knowledge and will trigger further research on related issues.

[1] We define capabilities as the capacity to perform activities deploying, coordinating, and utilizing a bundle of resources, which includes not only functional capabilities such as technological/marketing capabilities but also integrative capabilities that combine and align different capabilities, resulting in unique capabilities (Danneels, 2002; Henderson \& Cockburn, 1994; Kusunoki, Nonaka, \& Nagata, 1998; Makadok, 2001; Verona, 1999).

[2] Innovation in this study is defined as a series of valuecreation actions to transform new knowledge into 
economically vital products and bring them into a market.

[3] In this measurement model, all 31 measurement items that were hypothesized to measure 10 constructs were subjected to a single confirmatory factor analysis to ensure that the measures represented only their hypothesized constructs and evidenced acceptable reliability as well as convergent and discriminant validity. The individual measures were specified to load only on a single factor on the basis of theoretical definition.

[4] The degree of multicollinearity and its effect on the regression results were assessed by examining correlation matrix, variance inflation factor (VIF), tolerance values, and condition index. With raw data (before the $z$ transformation) the evidence of multicollinearity was observed in the values of VIF. After the $z$ transformation, however, no serious multicollinearity in the regression results was observed.

\section{References}

Aiken L.S. \& West, S.G. (1991). Multiple Regression: Testing and Interpreting Interactions. Thousand Oaks, CA: Sage.

Aldrich, H.E. (1999). Organization Evolving. London: Sage.

Aldrich, H.E. \& Martinez, M.A. (2001). Many are called, but few are chosen: An evolutionary perspective for the study of entrepreneurship. Entrepreneurship Theory and Practice, 25, 41-56.

Alpert, F.H., Kamins, M.A., \& Graham, J. (1992). An examination of reseller buyer attitudes toward order of brand entry. Journal of Marketing, 56, 25-37.

Alvarez, S.A. \& Barney, J.B. (2001). How entrepreneurial firms can benefits from alliances with large partners. Academy of Management Executive, $15,139-148$

Anderson, P. \& Tushman, M.L. (1990). Technological discontinuities and dominant designs: A cyclical model of technological change. Administrative Science Quarterly, 35, 604-633.

Ashforth, B.E. \& Gibbs, B.W. (1990). The double-edge of organizational legitimation. Organization Science, 1, 177-194.

Astley, W.G. \& Van de Ven, A.H. (1983). Central perspectives and debates in organizational theory. Administrative Science Quarterly, 28, 245-273.

Bain, J.S. (1959). Industrial Organizations. New York: Wiley.

Baum, J.A.C. \& Oliver, C. (1991). Institutional linkages and organizational mortality. Administrative Science Quarterly, 15, 11-28.

Brown, S.L. \& Eisenhardt, K.M. (1995). Product development: Past research, present findings, and future directions. Academy of Management Review, 20, 343-378.

Brush, C.G. \& Vanderwerf, P.A. (1992). A comparison of methods and sources for obtaining estimates of new venture performance. Journal of Business Venturing, 7, 157-170.

Chandy, R.K. \& Tellis, G.J. (2000). The incumbent's curse? Incumbency, size, and radical product innovation. Journal of Marketing, 64, 1-17.

Covin, J.G. \& D. P. Slevin, D.P. (1989). Strategic management of small firms in hostile and benign environments. Strategic Management Journal, $10,75-87$.

Covin, J.G., Slevin, D.P., Heeley, J., \& Michael, B. (2000). Pioneers and followers: Competitive tactics, environment, and firm growth. Journal of Business Venturing, 15, 175-210.

Danneels, E. (2002). The dynamics of product innovation and firm competences. Strategic Management Journal, 23, 1095-1121.

Deeds, D.L., Mang, P.Y., \& Frandsen, M.L. (2004). The influence of firm and industry legitimacy on the flow of capital into high technology ventures. Strategic Organization, 2, 9-34.

Deephouse, D.L. (1999). To be different, or to be the same? It's a question (and theory) of strategic balance. Strategic Management Journal, 20, 147-166.

Deshpande, R., Farley, J.U., \& Webster, F.E. (1993). 
Corporate culture customer orientation, and innovativeness in Japanese firms: A quadrad analysis. Journal of Marketing, 57, 23-37.

Dess, G.G. \& Beard, D.W. (1984). Dimensions of organizational task environment. Administrative Science Quarterly, 29, 52-73.

Dess, G.G. \& Robinson, R. (1984). Measuring organizational performance in the absence of objective measures: The case of privately-held firm and conglomerate business unit. Strategic Management Journal, 5, 265-283.

Dess, G.G., Lumpkin, G.T., \& Covin, J.G. (1997). Entrepreneurial strategy making and firm performance: Tests of contingency and configurational model. Strategic Management Journal, 18, 677-695.

Dierickx, I. \& Cool, K. (1989). Asset stock accumulation and sustainability of competitive advantage. Management Science, 35, 1504-1514.

DiMaggio, P. (1988). Interest and agency in institutional theory. In Institutional Patterns and Organizations: Culture and Environment. Cambridge, MA: Ballinger Pub. Co.

DiMaggio, P. \& Powell, W. (1983). The iron cage revisited: Institutional isomorphism and collective rationality in organizational fields. American Sociological Review, 48, 147-160.

Ethiraj, S., Kale, P., Krishnan, M.S., \& Singh, J. (2005). Where do capabilities come from and how do they matter: A study in the software service industry. Strategic Management Journal, 26, 25-45.

Gatignon, H. \& Xuereb, J. (1997). Strategic orientation of the firm and new product performance. Journal of Marketing Research, 34, 77-90.

Hambrick, D.C. \& D'Aveni, R.A. (1992). Top management team deterioration as part of the downward spiral of large bankruptcies. Management Science, 38, 1445-1466.

Hannan, M.T. \& Freeman, J.H. (1989). Organizational Ecology. Cambridge, MA: Harvard University Press.

Hargadon, A.B. \& Douglas, Y. (2001). When innovations meet institutional: Edison and the design of the electric light. Administrative Science Quarterly, 46, 476-501.

Henderson, R.M. \& Clark, K.B. (1990). Architectural innovation: The reconfiguration of existing product technologies and the failure of established firms. Administrative Science Quarterly, 35, 9-30.

Henderson, R. \& Cockburn, I. (1994). Measuring competence? Exploring firm effects in pharmaceutical research. Strategic Management Journal, 15, 63-84.

Higgins, M. \& Gulati, R. (2003). Getting off to a good start: The effects of upper echelon affiliations on interorganizational endorsements. Organization Science, 14, 244-263.

Higgins, M. \& Gulati, R. (2006). Stacking the deck: The effect of upper echelon affiliations for entrepreneurial firms. Strategic Management Journal, 27, 1-26.

Jassawalla, A.R. \& Sashittal, H.C. (2002). Cultures that support product-innovation processes. Academy of Management Executive, 16, 42-54.

Kalyanaram, G., Robinson, W.T., \& Urban, G.L. (1995). Order of market entry: Established empirical generalizations, emerging empirical generalizations, and future research. Marketing Science, 14, 212-221.

Khaire, M. (2010). Young and no money? Never mind: The material impact of social resources on new venture growth. Organization Science, 21, 168-185.

Kuratko, D.F. \& Brown, T.J. (2010). Emerging life science ventures: The quest for legitimacy. Business Horizons, 53, 211-220.

Kusunoki, K., Nonaka, I., \& Nagata, A. (1998). Organizational capabilities in product development of Japanese firms: A conceptual framework and empirical findings. Organization Science, 9, 699-718.

Lawrence, P.R. \& Lorsch, J.W. (1967). Organization and Environment, Managing Differentiation and Integration. Cambridge, MA: Harvard University Press.

Lounsbury, M.L. \& Glynn, M.A. (2001). Cultural entrepreneurship: Stories, legitimacy, and the acquisition of resources. Strategic Management Journal, 22, 545-564. 
Low, M.B. \& Abrahamson, E. (1997). Movements, bandwagons, and clones: Industry evolution and the entrepreneurial process. Journal of Business Venturing, $12,435-457$.

Lynn, G.S., Morone, J.G., \& Paulson, A.S. (1996). Marketing and discontinuous innovation: The probe and learn process. California Management Review, 38, 8-37.

Makadok, R. (2001). Toward a synthesis of the resource-based and dynamic-capability view of rent creation. Strategic Management Journal, 22, 387-401.

Meyer, J.W. \& Rowan, B. (1977). Institutionalized organizations: Formal structure as myth and ceremony. American Journal of Sociology, 83, 340-363.

Meznar, M.B. \& Nigh, D. (1995). Buffer or bridge? Environmental and organizational determinants of public affairs activities in American firms. Academy of Management Journal, 38, 975-996.

Mitchell, W. (1989). Whether and when? Probability and timing of incumbents' entry into emerging industrial subfields. Administrative Science Quarterly, 34, 208-230.

Nelson, R.R. \& Rosenberg, N. (1993). Technical innovation and national systems. In Nelson, R.R. (Ed.), National Innovation Systems: A Comparative Analysis. Oxford, U. K.: Oxford University Press.

Oliver, C. (1997). Sustainable competitive advantage: Combining institutional and resource-based view. Strategic Management Journal, 18, 697-713.

Pettigrew, A.M. (1979). On studying organizational cultures. Administrative Science Quarterly, 24, 570-581.

Pfeffer, J. \& Salancik, G.R. (1978). The External Control of Organizations. New York: Harper \& Row.

Powell, W.W., Koput, K.W., \& Smith-Doerr, L. (1996). Interorganizational collaboration and the locus of innovation: Networks of learning in biotechnology. Administrative Science Quarterly, 41, 116-145.

Rao, H. (1994). The social construction of reputation: Certification contests, legitimation, and the survival of organizations in the American automobile industry:
1895-1912. Strategic Management Journal, 15, 29-44.

Rao, R.S., Chandy, R.K., \& Prabhu, J.C. (2008). The fruits of legitimacy: Why some new ventures gain more from innovation than others. Journal of Marketing, $72,58-75$.

Roberts, P.W. (1999). Product innovation, productmarket competition and persistent profitability in the U.S. Strategic Management Journal, 20, 655-670.

Rogers, E.M. (1962). Diffusion of Innovations. New York: The Free Press of Glencoe.

Sandberg, W.R. \& Hofer, C.W. (1987). Improving new venture performance: The role of strategy, industry structure, and the entrepreneur. Journal of Business Venturing, 2, 5-28.

Schoonhoven, C.B., Eisenhardt, K.M., \& Lyman, K. (1990). Speeding products to market: Waiting time to first product introduction in new firms. Administrative Science Quarterly, 35, 177-207.

Schumpeter, J.A. (1934). The Theory of Economic Development. Cambridge, MA: Harvard University Press.

Scott, W.R. (1987). The adolescence of institutional theory. Administrative Science Quarterly, 32, 493-511.

Shane, S. \& Delmar, F. (2004). Planning for the market: Business planning before marketing and the continuation of organization efforts. Journal of Business Venturing, 19, 767-785.

Sine, W.D., David, R.J., \& Mitsuhashi, H. (2007). From plan to plant: Effects of certification on operational startup in the emergent independent power sector. Organization Science, 18, 578-594.

Singh, J.V., Tucker, D.J., \& House, R.J. (1986). Organizational legitimacy and the liability of newness. Administrative Science Quarterly, 31, 171-193.

Song, X.M. \& Parry, M.E. (1997). The determinants of Japanese new product successes. Journal of Marketing Research, 34, 64-76.

Stinchcombe, A.L. (1965). Social structure and organizations. In March, J.G. (Ed.), Handbook of Organizations. Chicago: Rand McNally. 
Stuart, T.E., Hoang, H., \& Hybels, R.C. (1999). Interorganizational endorsement and the performance of entrepreneurial ventures. Administrative Science Quarterly, 44, 315-349.

Suchman, M.C. (1995). Managing legitimacy: Strategic and institutional approaches. Academy of Management Review, 20, 571-610.

Teece, D.J. (1986). Profiting from technological innovation: Implication for integration, collaboration, licensing, and public policy. Research Policy, 15, 285-305.

Timmons, J.A. (1999). America's $E$ ntrepreneurial Revolution. Babson Park, MA: Babson College.

Tushman, M.L. \& Anderson, P. (1986). Technological discontinuities and organizational environments. Administrative Science Quarterly, 31, 439-465.

Van de Ven, A.H. (1986). Central problems in the management of innovation. Management Science, 32, 590-607.

Van de Ven, A.H. \& Garud, R. (1994). The convolution of technical and institutional events in the development of an innovation. In Baum, J. \& Singh, J. (Eds.), Evolutionary Dynamics of Organizations. Oxford: Oxford University Press.

Verona, G. (1999). A resource-based view of product development. Academy of Management Review, 24, 132-142.

Williamson, O.E. (1991). Comparative economic organization: The analysis of discrete structural alternatives. Administrative Science Quarterly, 36, 269-296.

Zahra, S.A. \& Bogner, W.C. (2000). Technology strategy and software new ventures' performance: Exploring the moderating effects of the competitive environment. Journal of Business Venturing, $15,135-173$.

Zott, C. \& Huy, Q.N. (2007). How entrepreneurs use symbolic management to acquire resources. Administrative Science Quarterly, 52, 70-105.

Zucker, L.G. (1987). Institutional theories of organization. In Scott, W.R. \& Short, J.F.Jr. (Eds.), Annual Review of Sociology, 13, 443-464. Palo Alto, CA: Annual Reviews.

\section{Appendix}

Items in Scales ${ }^{\mathrm{a}}$ \#footnotea)

Radicality

1.

We introduce products that are radically different from existing products. (PRA1)

2.

We are well-known for introducing breakthroughtype products. (PRA2)

3.

We are among the first-to-market with new products. (PRA3)

\section{Product breadth}

4.

We offer a wider variety of products than do our major competitors. (PBR1)

5.

We offer a broad line of products relative to our major competitors. (PBR2)

6.

Our product line is more diverse than those of our major competitors. (PBR3)

\section{Product advantage}

7.

Our products have superior performance relative to competing products. (PAD1)

8.

Our products are clearly superior to competing products in terms of meeting customer needs. (PAD2)

\section{Internal legitimacy of innovation}

9.

We consider 'risk-taking' a positive attitude that 
allows us to seize opportunities. (INC1)

10.

Our company is a very dynamic and entrepreneurial place. (INC2)

11.

Our corporate culture values creativity. (INC3)

\section{Media firm legitimation}

12.

We receive considerable positive press coverage about our firm, or its products or service. (LMF1)

13.

We attract more positive media coverage than our major competitors do. (LMF2)

14.

Many articles in the press refer positively to our firm, or its products/services. (LMF3)

\section{Endorsement}

15.

Our top managers are well networked with prominent individuals and use these connections to help our business. (LEN1)

16.

We affiliate with various prestigious

organizations. (LEN2)

17.

We have strong endorsements from influential organizations that increase the credibility of our company and products. (LEN3)

\section{Regulatory pressure}

18.

Our industry is heavily regulated by the government. (INP1)

19.

Regulatory requirements affect a large part of our activities. (INP2)

20.

Compliance with government regulation is of great importance for firm success. (INP3)
21.

We face a high level of pressure to act in accordance with standards for industry practice. (INP4)

22

We are under significant pressure to obey the rules of our industry. (INP5)

\section{Internal marketing resources}

23.

Our company has a high level of advertising/promotional expenditures relative to its major competitors. (IMR1)

24.

We have a strong sales force relative to our major competitors. (IMR2)

25.

We have a strong distributing channel relative to our major competitors. (IMR3)

a The code names in parentheses are those listed in Table 2. 